\title{
Fish Oil and the Prevention and Regression of Atherosclerosis
}

\author{
Loes M.A. Sassen, ${ }^{1}$ Jos M.J. Lamers ${ }^{2}$ and \\ Pieter $D$. Verdouw ${ }^{1}$ \\ ${ }^{1}$ Experimental Cardiology, Thoraxcenter and ${ }^{2}$ Department of \\ Biochemistry (The Cardiovascular Research Institute COEUR), \\ Erasmus University Rotterdam, Rotterdam, The Netherlands
}

Summary. Epidemiological studies in the seventies have put forward that dietary rather than genetic factors are responsible for the lower incidence of ischemic heart disease in Greenland Inuit and have generated a large body of both in vitro and in vivo experimental studies, exploring the putative favorable effects of fish (oil) on atherogenesis and its risk factors. The first part of this report reviews the in vivo animal studies, concentrating on the hypercholesterolemic models and the arterialized vein graft model. In the hypercholesterolemic animal studies, the results are inconclusive as the studies reporting a protective effect are matched by the number of studies showing no effect or an adverse effect. The diversity in species, dose of fish oil, duration of study, type of vessel studied and type of fish oil preparation (content of n-3 fatty acids, unesterified n-3 fatty acids, ethylesters or triglycerides) could all contribute. Furthermore, the definitions and criteria used in the literature to evaluate atherogenesis are diverse and it appears that while one parameter is affected, another is not necessarily modified in the same direction, stressing the importance of extending the analysis of the effects on atherogenesis to more than one parameter. We also believe that it is time to reach a consensus as to which animal model mimicks most closely a particular human situation. Only in appropriate models, investigating more than one atherosclerosis variable, can the effects of a putative anti-atherogenic drug or diet be verified. In the veno-arterial autograft model, mimicking the patient after coronary bypass grafting, dietary fish oil has been consistently effective in preventing accelerated graft intima proliferation. It could therefore be of interest to evaluate the effects of fish oil on graft patency in patients after coronary bypass surgery after a period of years.

The results from studies on restenosis after percutaneous transluminal angioplasty are also reviewed and it is concluded that the two large scale trials, that are currently underway, might reliably answer the question whether fish oil is effective as a non-pharmacological adjuvants in the prevention of restenosis.

Lastly, the studies on the effects of fish oil on the regression of experimental atherosclerosis are reviewed. In view of the small number of studies (i.e., four) investigating the effects of fish oil on the regression of atherosclerosis, it is premature to draw any conclusion, and therefore further experimental work is required.

Cardiovasc Drugs Ther 1994;8:179-191

Key Words. fish oil, atherosclerosis, progression, regression, animal studies, vein graft, restenosis
In the seventies it was shown that a cohort of Eskimos (Inuit), living in the Uummannaq district on the Westcoast of Greenland had low levels of plasma cholesterol, triglycerides and very low density lipoprotein (VLDL) and high levels of high density lipoprotein (HDL) [1]. Furthermore the official mortality statistics showed that the incidence of ischemic heart disease was low among Greenlanders. It must be kept in mind, however, that these mortality statistics are not very reliable as in Greenland most deaths occur at home or in small hospitals where diagnostic facilities are poor. The data do also not differentiate between native Greenlanders (80\%) and Danes. The establishment of a computerized death register for Greenland has yielded a more specified judgment of the mortality data [2] and ischemic heart disease as a cause of mortality indeed seems to be lower among Eskimos living in Greenland (6.7\% among males aged 45-64) than among Eskimos living in Denmark $(32.8 \%)$ in the years 1979-1983. These findings have been attributed to the dietary habits of the Greenland Eskimos who traditionally consume about $400 \mathrm{~g}$ of seal and fish per day. Although only 130 Eskimos were included in those early studies [1] and no direct proof of the lower incidence of coronary artery disease was offered by means of coronary angiography or otherwise, the observation of low mortality from ischemic heart disease among Greenland Eskimos in combination with their low risk plasma lipid profile has initiated a considerable amount of studies investigating the effect of the long chain polyunsaturated n-3 fatty acid containing fish (oil) products on risk factors of atherogenesis. With respect to the other accepted risk factors for ischemic heart disease, it is important to note that the Eskimo's diet is low in saturated fat, the Eskimos are rarely obese, hypertension is uncommon,

Address for correspondence: P.D. Verdouw, Experimental Cardiology, Thoraxcenter, Erasmus University Rotterdam, P.O. Box 1738, 3000 DR Rotterdam, The Netherlands.

Received 24 March 1993, accepted in revised form 20 October 1993 
and diabetes mellitus is unknown. On the other hand, most Eskimos are heavy smokers.

\section{Fish Oil and Factors Affecting Atherogenesis}

N-3 polyunsaturated fatty acids have their first double bond at the third carbon atom from the methyl end of the fatty acid. The very long chain fatty acids from the $n-3$ family, eicosapentaenoic $(20: 5 n-3$ or EPA), docosapentaenoic (22:5n-3 or DPA) and docosahexaenoic (22:6n-3 or DHA) are synthetized by algae and phytoplankton, organisms that are at the bottom of the marine food chain. All marine life may, therefore, ultimately be enriched with these fatty acids which may provide the required degree of unsaturation that allows cell membranes to remain fluid in cold water. Incorporation of dietary n-3 polyunsaturated fatty acids $(20: 5 n-3$ and $20: 6 n-3)$ in blood cell, vascular endothelial and vascular smooth muscle cell membrane of men leads to specific displacement of $n-6$ polyunsaturated arachidonic acid $(20: 4 n-6)$. N-3 fatty acids are poor substrates for cyclooxygenase and compete with 20:4n-6 at the level of cyclo-oxygenase and lipoxygenase thereby generating a different family of prostanoids and leukotrienes which have weak or almost no activity as compared to their 20:4n-6-derived analogues. This interference of $n-3$ fatty acids with eicosanoid metabolism may alter vasomotor tone and thrombotic and inflammatory responses that are critical to plaque formation following endothelial injury. In addition to the effects on intracellular mediators such as prostaglandins and leukotrienes, more recent evidence shows that $n-3$ fatty acids also interfere with the phosphatidylinositol (PI) cycle [3-5]. This is an intracellular signal transduction pathway that links various stimuli such as mechanical stress, hormone-, and growth factor-receptor interaction to their responses at the transcriptional level through the formation of the protein kinase activators $\mathrm{Ca}^{2+}$-calmodulin and diacylglycerol [6-8]. Many processes generally believed to play a role in atherogenesis, such as expression of leucocyte adhesion molecules [8], mechanical stress responses of endothelium [7], secretion of "endothelial-derived factors" [9] and mitogenic responses of vascular smooth muscle cells [6] involve operation of the PI cycle, thereby providing n-3 fatty acids an additional mechanism to interfere in the atherosclerotic process.

In Table 1 , by citing references $10-39$, we have summarized the known effects of $n-3$ fatty acids on functions of various cell types and levels of certain blood constituents, all influencing the processes believed to be involved in atherogenesis. These processes, intima hyperplasia and lipid infiltration, thrombosis, vascular smooth muscle tone and in- flammation are depicted horizontally, while the cells (endothelial cells, vascular smooth muscle cells, platelets, neutrophils and monocytes and blood constituents (lipoproteins and coagulation factors) that are involved in these processes are listed vertically (Table 1). At the sites where the columns and rows meet the known effects of $n-3$ fatty acids are mentioned. These effects, particularly the inhibition of platelet aggregation and the lengthening of bleeding time, have been reviewed several times [40-47] and we have therefore limited ourselves to discuss the effect of fish oil on the prevention and regression of atherosclerosis in different in vivo animal models and to review the effect of fish oil on restenosis following percutaneous transluminal coronary angioplasty.

\section{Animals used in the study on atherogenesis}

In studying atherosclerosis the choice of the species is important [48]. Rabbits have been used extensively in the study of atherosclerosis, but it is important to note that rabbits do not develop atherosclerosis naturally. However, when fed diets containing high levels of cholesterol massive amounts of cholesterol accumulate in the tissues and in the arterial wall [49]. In this species, the aortic arch and the intramural myocardial arterioles are affected [49] whereas in humans the abdominal aorta and the proximal main coronary arteries are involved. Importantly, the lesions in rabbits are chiefly fatty and complicated features such as fibrosis, ulceration and thrombosis seldom occur. When rabbits are fed casein in addition to saturated fat they do develop advanced lesions located in the abdominal aorta [50]. Swine do develop atherosclerosis spontaneously from 6 months of age onward (although serious lesions are only seen after 6-7 years) with the early occurring lesions closely resembling human lesions $[51,52]$, and the location (abdominal aorta and proximal coronary arteries) being similar to that in man. Severe and accelerated atherosclerosis can be achieved in pigs by combining hypercholesterolemia with endothelial injury $[53,54]$. Dogs, on the other hand, hardly develop atherosclerosis, even after changing to a high cholesterol diet. Only after additional interventions, such as removal or destruction of the thyroid gland, lesions become severe and their severity are highly correlated with the degree of hypercholesterolemia. The location of the lesions in the arterial tree is similar to that in humans, but there is much more medial involvement than in other species and man [55]. Diet-induced atherosclerosis in rhesus and cynomolgus monkeys most closely resemble human atherosclerosis both anatomically and morphologically $[56,57]$. Nevertheless, it must be noted that also in this species there are hyper- and hyporesponders to a high cholesterol diet while the extent of atherosclerosis also varies considerably. These findings, however, appear to be characteristic for all species including man. 
Table 1. Effects of $n-3$ fatty acids on cell functions and blood constituents possibly involved in atherosclerosis

\begin{tabular}{|c|c|c|c|c|}
\hline & $\begin{array}{l}\text { Intimal hyperplasia \& } \\
\text { lipid infiltration }\end{array}$ & Platelet aggregation & $\begin{array}{l}\text { Vascular smooth } \\
\text { muscle tone }\end{array}$ & Inflammation \\
\hline Platelets & $\begin{array}{l}\text { factor } 4 \downarrow^{10}, \beta \text { - } \\
\text { thromboglobulin } \downarrow^{10,11} \text {, } \\
\text { PAF } \downarrow^{12} \text {, platelet } \\
\text { survival } \uparrow^{13}\end{array}$ & $\begin{array}{c}\text { TXA }_{2} \downarrow^{11,13,14}, \mathrm{TXA}_{3} \\
\uparrow^{11,13,14} \text {, platelet } \\
\text { count } \downarrow^{15} \text {, bleeding } \\
\text { time } \downarrow \uparrow 15,16\end{array}$ & $\mathrm{TXA}_{2} \downarrow^{11,13,14}, \mathrm{TXA}_{3} \uparrow^{11,13,14}$ & \\
\hline Endothelial cell & PDGF $\downarrow^{17}$ & $\begin{array}{l}\mathrm{PGI}_{3} \uparrow 11,13,14, \mathrm{PGI}_{2} \\
\quad \text { preserved }{ }^{11,13,14}, \mathrm{EDRF} \\
\quad \text { effect } \uparrow 18,19\end{array}$ & $\begin{array}{l}\mathrm{PGI}_{3} \uparrow 11,13,14, \mathrm{EDRF} \\
\quad \text { effect } \uparrow 18,19\end{array}$ & \\
\hline Lipoproteins & $\begin{array}{l}\text { VLDL } \downarrow^{20,21} \text {, } \\
\text { triglycerides } \downarrow^{20,21} \text {, } \\
\text { LDL } \downarrow \uparrow={ }^{20,21} \text {, HDL } \\
\downarrow \uparrow=20,21 \text {, change in } \\
\text { lipoprotein size; } \\
\text { apoprotein content; } \\
\text { physical properties; } \\
\text { lipoprotein metabolism; } \\
\text { lipid peroxidation }{ }^{22-25}\end{array}$ & & & \\
\hline Monocyte & IL-1; TNF $\downarrow^{26}$ & PAF $\downarrow^{12}$ & & $\mathrm{LTB}_{4} \downarrow ; \mathrm{LTB}_{5} \uparrow 27$ \\
\hline Neutrophil & $\begin{array}{l}\mathrm{LTB} \downarrow 4 ; \mathrm{LTB}_{5} \uparrow^{27}, \text { free } \\
\text { radical synthesis } \downarrow^{28}, \\
\text { chemotaxis } \downarrow^{29}\end{array}$ & & & $\begin{array}{l}\mathrm{LTB}_{4} \downarrow ; \mathrm{LTB}_{5} \uparrow^{27}, \\
\text { adhesion and } \\
\text { chemotaxis } \downarrow^{29}\end{array}$ \\
\hline $\begin{array}{l}\text { Vascular smooth } \\
\text { muscle cell }\end{array}$ & & & $\begin{array}{l}\text { blood pressure } \downarrow \uparrow^{30} \\
\text { response to } \\
\text { noradrenaline } \downarrow^{31}\end{array}$ & \\
\hline $\begin{array}{l}\text { Coagulation } \\
\text { factors }\end{array}$ & & $\begin{array}{l}\text { fibrinogen }=\downarrow \uparrow 32-34, \\
\text { PAI-1 } \downarrow \uparrow 35,36 \text {, factor } \\
\text { VII }=\uparrow 32,33,37,38, \\
\text { antithrombin }= \\
\downarrow^{29,32,37,39}, \text { tPA } \uparrow={ }^{36,37}, \\
\text { von Willebrand }={ }^{32}\end{array}$ & & \\
\hline
\end{tabular}

Based on Israel DH and Gorlin R (reference 45); PAF = platelet aggregating factor; $\mathrm{TX}=$ tromboxane; PDGF $=$ platelet derived growth factor; $\mathrm{PG}=$ prostaglandin; $\mathrm{EDRF}=$ endothelium derived relaxing factor; VLDL, LDL and HDL = very low, low and high density lipoproteins, respectively; $\mathrm{IC}=$ interleukine; $\mathrm{TNF}=$ tumor necrosis factor; $\mathrm{LT}=$ leutotriene; $\mathrm{PAF}=$ platelet aggregating factor; $\mathrm{tPA}=$ tissue plasminogen activator; = unchanged; $\downarrow$ decrease; $\uparrow$ inerease.

\section{Fish Oil and the Prevention of Atherosclerosis}

\section{Animal studies with hypercholesterolemia}

Tables 2-4 list the in vivo studies in rabbits [58-69], swine $[23,28,70-73]$ and monkeys [74-76], respectively, on the effects of fish oil on the prevention of atherosclerosis and provides details such as the dietary regimen, duration of study, etc. Except in the Watanabe hereditary hyperlipidemic rabbit and one study in pigs [73], all atherogenic diets are highcholesterol diets, and in case of the swine model $[28,70-72]$, bile acids were also needed to enhance hypercholesterolemia. In small animals (rabbits) usually only the aorta has been used to evaluate the anti-atherogenic effect of fish oil. The effects in coronary arteries have only been studied in the larger mammals (the swine and non-human primates). Five $[58-60,63,64]$ of the hypercholesterolemic rabbit studies mentioned in Table 2 are very similar in design as a high-cholesterol diet was used to stimulate athero- genesis and its progress was evaluated by determining the percentage of the area covered with sudanophilic lesions. The large discrepancy in the severity of the degree of atherosclerosis and the employed regimen to induce atherosclerosis is most clearly illustrated by the finding that in one study [63] the control animals had $30 \%$ of the aorta covered with lesions when they were fed $1 \%$ cholesterol with a dietary period of 8 weeks, while in another study [60] sudanophilia of the aorta was twice as high after feeding a much lower $(0.3 \%)$ amount of dietary cholesterol, only two weeks longer, illustrating that even within a certain species the variability of response to highcholesterol feeding can be very high.

In most studies the description of the diets is insufficient to calculate the daily administered amount of n-3 polyunsaturated fatty acids (subdivided into 20 : 5n-3 and 22:6n-3). This information may, however, be important in deciding whether fish oil has antiatherogenic potential. In Tables $2-4$ the dose of fish oil is presented as the daily intake of fish oil in $\mathrm{ml}$ and, 
Table 2. Studies on the effect of fish oil on atherogenesis in the hypercholesterolemic rabbit

\begin{tabular}{|c|c|c|c|c|c|c|c|}
\hline & & $\begin{array}{l}\text { Time } \\
\text { (months) }\end{array}$ & $\begin{array}{l}\text { Dose of EPA } \\
\text { and/or DHA }\end{array}$ & $\mathrm{I} / \mathrm{S}$ & $\begin{array}{l}\text { Blood vessel } \\
\text { studied }\end{array}$ & $\begin{array}{l}\text { Assessment of } \\
\text { atherosclerosis }\end{array}$ & $\begin{array}{l}\text { Effect of } \\
\text { fish oil }\end{array}$ \\
\hline Thiery and Seide ${ }^{58}$ & $\begin{array}{l}\text { hypercholes- } \\
\text { terolemia }\end{array}$ & 5 & $2 \mathrm{ml} \mathrm{MaxEpa/day}$ & $\mathrm{S}$ & Aorta & \%lesions & $\uparrow$ \\
\hline Kristensen et al..$^{59}$ & $\begin{array}{l}\text { hypercholes- } \\
\text { terolemia }\end{array}$ & 1.75 & $\begin{array}{l}3 \mathrm{ml} \mathrm{MaxEpa/day:} 130^{\mathrm{a}}- \\
80^{\mathrm{b}} \text { total n-3 (mg/ani- } \\
\mathrm{mal} / \text { day) }\end{array}$ & I & Aorta & \%lesions & $=$ \\
\hline \multirow[t]{6}{*}{ Zhu et al. ${ }^{60}$} & \multirow[t]{6}{*}{$\begin{array}{l}\text { hypercholes- } \\
\text { terolemia }\end{array}$} & \multirow[t]{6}{*}{2.5} & $\begin{array}{l}1 \text { ml Proto Chol mix: } \\
\text { per kg per day }\end{array}$ & $\mathrm{S}$ & Aorta & \%lesions & $=$ \\
\hline & & & $\begin{aligned}= & (113 \mathrm{EPA}+75 \\
& \mathrm{DHA})^{\mathrm{a}}-(55 \mathrm{EPA}+ \\
& 36 \mathrm{DHA})^{\mathrm{b}}(\mathrm{mg} / \mathrm{kg} / \\
& \text { day })\end{aligned}$ & & $\begin{array}{l}\text { Pulmonary } \\
\text { artery }\end{array}$ & \%lesions & $\downarrow$ \\
\hline & & & $\begin{array}{l}2 \text { ml Proto-Chol mix: } \\
\text { per kg per day }\end{array}$ & $\mathrm{S}$ & Aorta & \%lesions & $\downarrow$ \\
\hline & & & $\begin{aligned}= & (226 \mathrm{EPA}+150 \\
& \mathrm{DHA})^{\mathrm{a}}-(103 \mathrm{EPA} \\
& +69 \mathrm{DHA})^{\mathrm{b}}(\mathrm{mg} / \mathrm{kg} / \\
& \text { day })\end{aligned}$ & & $\begin{array}{l}\text { Pulmonary } \\
\text { artery }\end{array}$ & \%lesions & $\downarrow$ \\
\hline & & & $\begin{array}{l}3 \text { ml Proto-Chol mix: } \\
\text { per kg per day }\end{array}$ & $\mathrm{S}$ & Aorta & \%lesions & $\downarrow$ \\
\hline & & & $\begin{array}{l}=(257 \mathrm{EPA}+171 \\
\mathrm{DHA})^{\mathrm{a}}-(146 \mathrm{EPA} \\
+97 \mathrm{DHA})^{\mathrm{b}}(\mathrm{mg} / \mathrm{kg} / \\
\text { day })\end{array}$ & & $\begin{array}{l}\text { Pulmonary } \\
\text { artery }\end{array}$ & \%lesions & $\downarrow$ \\
\hline Campos et al. ${ }^{61}$ & $\begin{array}{l}\text { hypercholes- } \\
\text { terolemia }\end{array}$ & 3 & $\begin{array}{c}100 \mathrm{EPA}+59 \mathrm{DHA} \\
(\mathrm{mg} / \mathrm{kg} / \mathrm{day})\end{array}$ & $\mathrm{S}$ & Aorta & aortic lipids & $\mathrm{TC}=$ \\
\hline Rogers and Adelstein ${ }^{62}$ & $\begin{array}{l}\text { hypercholes- } \\
\text { terolemia }\end{array}$ & 1 & $\begin{array}{l}2.5 \mathrm{ml} \mathrm{MaxEpa:} 0.5 \mathrm{ml} \\
\mathrm{MaxEpa} / \mathrm{kg}\end{array}$ & I & $\begin{array}{l}\text { Aorta (tho- } \\
\text { racic) }\end{array}$ & intimal foam cells & $\uparrow$ \\
\hline \multirow[t]{2}{*}{ Yamaguchi et al. ${ }^{63}$} & \multirow[t]{2}{*}{$\begin{array}{l}\text { hypercholes- } \\
\text { terolemia }\end{array}$} & \multirow[t]{2}{*}{2} & $\begin{array}{l}10 \mathrm{mg} / \mathrm{kg} \text { EPA-E: } 7.5 \\
\mathrm{EPA}+0.9 \mathrm{DHA} \\
(\mathrm{mg} / \mathrm{kg} / \text { day })\end{array}$ & $\mathrm{S}$ & Aorta & \%lesions & $=$ \\
\hline & & & $\begin{array}{c}30 \mathrm{mg} / \mathrm{kg} \text { EPA-E; } 22.5 \\
\mathrm{EPA}+2.7 \mathrm{DHA} \\
(\mathrm{mg} / \mathrm{kg} / \text { day })\end{array}$ & & Aorta & \%lesions & $=$ \\
\hline \multirow[t]{2}{*}{ Chen et al. ${ }^{64}$} & \multirow[t]{2}{*}{$\begin{array}{c}\text { hypercholes- } \\
\text { terolemia }\end{array}$} & \multirow[t]{2}{*}{6} & \multirow[t]{2}{*}{$3 \% \mathrm{EPA}-2 \% \mathrm{DHA}$} & \multirow[t]{2}{*}{$\mathrm{S}$} & Aorta & \%lesions & $\downarrow$ \\
\hline & & & & & $\begin{array}{l}\text { Pulmonary } \\
\text { artery }\end{array}$ & \%lesions & $\downarrow$ \\
\hline \multirow[t]{2}{*}{ Hearn et al. ${ }^{65}$} & \multirow[t]{2}{*}{$\begin{array}{l}\text { hypercholes- } \\
\text { terolemia } \\
(+ \text { abra- } \\
\text { sion })\end{array}$} & \multirow[t]{2}{*}{1.5} & \multirow[t]{2}{*}{$0.3 \mathrm{ml} \mathrm{MaxEpa} / \mathrm{kg} /$ day } & \multirow[t]{2}{*}{$\mathrm{S}$} & Aorta & $\begin{array}{l}\text { luminal area } \\
\text { vessel wall thickness }\end{array}$ & $\begin{array}{l}= \\
\uparrow\end{array}$ \\
\hline & & & & & Iliac artery & $\begin{array}{l}\text { luminal diameter (angi- } \\
\text { ography) }\end{array}$ & $\downarrow$ \\
\hline Bolton-Smith et al. ${ }^{66}$ & $\begin{array}{l}\text { hypercholes- } \\
\text { terolemia } \\
(+ \text { horse } \\
\text { serum })\end{array}$ & 12 & $20 \mathrm{ml}$ fish oil $/ \mathrm{kg} /$ day & I & Aorta & \%lesions & $\begin{array}{l}\downarrow \text { vs coco- } \\
\text { nut oil } \\
=\text { vs corn } \\
\text { oil }\end{array}$ \\
\hline $\begin{array}{l}\text { Lichtenstein and } \\
\text { Chobanian }{ }^{67}\end{array}$ & $\begin{array}{l}\text { hypercholes- } \\
\text { terolemia } \\
\text { (WHHL- } \\
\text { rabbit) }\end{array}$ & 6 & $\begin{array}{l}260 \mathrm{EPA}+210 \mathrm{DHA} \\
(\mathrm{mg} / \mathrm{kg} / \mathrm{day})\end{array}$ & $\mathrm{s}$ & $\begin{array}{l}\text { Aorta } \\
\text { Aorta (de- } \\
\text { scending) }\end{array}$ & $\begin{array}{l}\text { \%lesions } \\
\text { aortic lipids }\end{array}$ & $\begin{array}{l}= \\
\mathrm{FC} \downarrow ; \mathrm{CE} \downarrow\end{array}$ \\
\hline Clubb et al. ${ }^{68}$ & $\begin{array}{l}\text { hypercholes- } \\
\text { terolemia } \\
\text { (WHHL- } \\
\text { rabbit) }\end{array}$ & 5 & $\begin{array}{l}150-200 \mathrm{EPA}(\mathrm{mg} / \mathrm{kg} / \\
\text { day); DHA?? }\end{array}$ & $\mathrm{S}$ & $\begin{array}{l}\text { Aorta (ab- } \\
\quad \text { dominal) } \\
\text { Aorta (total) } \\
\text { Aorta }\end{array}$ & $\begin{array}{l}\text { \%lesions } \\
\text { intimal thickness } \\
\text { subendothelial lipid accu- } \\
\text { mulation }\end{array}$ & $\begin{array}{l}\uparrow \\
= \\
\uparrow\end{array}$ \\
\hline Rich et al. ${ }^{69}$ & $\begin{array}{l}\text { hypercholes- } \\
\text { terolemia } \\
\text { (WHHL- } \\
\text { rabbit) }\end{array}$ & 12 & $\begin{array}{l}0.4 \mathrm{ml} \text { MaxEpa per day: } \\
90-120 \text { EPA }(\mathrm{mg} / \mathrm{kg} / \\
\text { day); DHA?? }\end{array}$ & $\mathrm{S}$ & Aorta & $\begin{array}{l}\text { \%lesions } \\
\text { average lesion thickness }\end{array}$ & $\begin{array}{l}= \\
=\end{array}$ \\
\hline
\end{tabular}

EPA, eicosapentaenoic acid (20:5n-3); DHA, docosahexaenoic acid $(20: 6 n-3)$; ${ }^{a}$ dose at the beginning of the dietary period; ${ }^{b}$ dose at the end of the dietary period; I/S, isocaloric or supplementary administration of fish oil; \%lesions stands for the percentage of the surface of the vessel that is covered with intimal lesions; LE, luminal eneroachment; FC, free cholesterol; CE, esterified cholesterol; TC, total cholesterol; WHHL, Watanabe hyperlipidemic; Effect of fish oil: $=$, unchanged; $\downarrow$ decrease; $\uparrow$, increase. 
Table 3. Studies on the effect of fish oil on models of accelerated atherogenesis in pigs

\begin{tabular}{|c|c|c|c|c|c|c|c|}
\hline Author & Animal model & $\begin{array}{l}\text { Time } \\
\text { (months) }\end{array}$ & $\begin{array}{l}\text { Dose of EPA } \\
\text { and/or DHA }\end{array}$ & $\mathrm{I} / \mathrm{S}$ & $\begin{array}{l}\text { Blood } \\
\text { vessel } \\
\text { studied }\end{array}$ & $\begin{array}{l}\text { Parameter of } \\
\text { atherosclerosis }\end{array}$ & $\begin{array}{l}\text { Effect of } \\
\text { fish oil }\end{array}$ \\
\hline \multirow[t]{2}{*}{ Hill et al. ${ }^{70}$} & \multirow[t]{2}{*}{$\begin{array}{l}\text { hypercholesterolemia } \\
\quad+\text { bile acids }\end{array}$} & \multirow[t]{2}{*}{24} & $6 \%$ total $n-3$ (weight $\%$ in diet) & $\mathrm{I}^{\mathrm{a}}$ & $\begin{array}{c}\text { Coronary } \\
\text { artery }\end{array}$ & $\begin{array}{l}\mathrm{LE}^{b} \\
\text { \%lesions } \\
\text { aortic lipids } \\
\mathrm{LE}^{\mathrm{b}}\end{array}$ & $\begin{array}{l}= \\
= \\
\mathrm{FC}=; \mathrm{CE}= \\
=\end{array}$ \\
\hline & & & $3 \%$ total $n-3$ (weight\% in diet) & $\mathrm{I}^{\mathrm{e}}$ & $\begin{array}{c}\text { Coronary } \\
\text { artery }\end{array}$ & $\begin{array}{l}\mathrm{LE}^{\mathrm{b}} \\
\text { \%lesions } \\
\text { aortic lipids } \\
\mathrm{LE}^{\mathrm{b}}\end{array}$ & $\begin{array}{l}\downarrow \\
\downarrow \\
\mathrm{FC}=; \mathrm{CE}= \\
\downarrow\end{array}$ \\
\hline Hill et al. ${ }^{71}$ & $\begin{array}{l}\text { hypercholesterolemia } \\
\quad+\text { bile acids }\end{array}$ & 12 & $3 \%$ total $n-3$ (weight $\%$ in diet) & I & $\begin{array}{c}\text { Coronary } \\
\text { artery }\end{array}$ & $\begin{array}{l}\mathrm{LE}^{\mathrm{b}} \\
\text { \%lesions } \\
\text { aortic lipids } \\
\mathrm{LE}^{\mathrm{b}}\end{array}$ & $\begin{array}{l}= \\
= \\
\mathrm{FC}=; \mathrm{CE}= \\
=\end{array}$ \\
\hline Weiner et al. ${ }^{72}$ & $\begin{array}{l}\text { hypercholesterolemia } \\
\quad+\text { bile acids }+ \\
\text { abrasion }\end{array}$ & 8 & $30 \mathrm{ml}$ cod liver oil per day per animal & S & $\begin{array}{l}\text { Coronary } \\
\text { artery }\end{array}$ & LE & $\downarrow$ \\
\hline Kim et al..$^{23}$ & $\begin{array}{l}\text { hypercholesterolemia } \\
\quad+\text { bile acids }\end{array}$ & 4 & $\begin{array}{l}(330 \mathrm{EPA}+330 \mathrm{DHA})^{\mathrm{d}}-(100 \mathrm{EPA} \\
\quad+100 \mathrm{DHA})^{\mathrm{e}}(\mathrm{mg} / \mathrm{kg} / \mathrm{day})^{\mathrm{e}}\end{array}$ & $S$ & $\begin{array}{l}\text { Aorta } \\
\text { Coronary } \\
\quad \text { artery }\end{array}$ & $\begin{array}{l}\mathrm{LE} \\
\mathrm{LE}\end{array}$ & $\downarrow$ \\
\hline Hartog et al. ${ }^{73}$ & $\begin{array}{l}\text { normocholesterolemia } \\
\quad+\text { teflon constric- } \\
\text { tor }\end{array}$ & 4 & $\begin{array}{l}0.36 \% \mathrm{EPA}+0.23 \% \mathrm{DHA} \text { (weight \% } \\
\text { in diet) }\end{array}$ & I & $\begin{array}{l}\text { Coronary } \\
\text { artery }\end{array}$ & LE & $\downarrow$ \\
\hline \multirow[t]{2}{*}{ Sassen et al. ${ }^{28}$} & \multirow[t]{2}{*}{$\begin{array}{l}\text { hypercholesterolemia } \\
+ \text { bile acids }+ \\
\text { abrasion }\end{array}$} & \multirow[t]{2}{*}{8} & \multirow[t]{2}{*}{$\begin{array}{l}(1040 \mathrm{EPA}+743 \mathrm{DHA})^{\mathrm{d}}-(242 \mathrm{EPA} \\
\quad+175 \mathrm{DHA})^{\mathrm{e}}(\mathrm{mg} / \mathrm{kg} / \text { day })\end{array}$} & \multirow[t]{2}{*}{1} & Aorta & $\begin{array}{l}\text { \%lesions } \\
\text { aortic lipids }\end{array}$ & $\begin{array}{l}= \\
=\end{array}$ \\
\hline & & & & & $\begin{array}{l}\text { Coronary } \\
\text { artery }\end{array}$ & LE & $\overline{=}$ \\
\hline
\end{tabular}

EPA, eicosapentaenoic acid (20:5n-3); DHA, docosahexaenoic acid (20:6n-3); ${ }^{2}$ tallow used as control diet; ${ }^{b}$ semiquantitative histologic grading; coconut-oil used as control diet; dose at the beginning of the dietary period; ${ }^{\text {dodose }}$ at the end of the dietary period; I/S, isocaloric or supplementary administration of fish oil; \%lesions stands for the percentage of the surface of the vessel that is covered with intimal lesions; LE, luminal encroachment; FC, free cholesterol; CE, esterified cholesterol; Effect of fish oil: =, unchanged; $\downarrow$, decrease; $\uparrow$, increase.

where possible also as mg n-3 fatty acids (subdivided into the major long chain polyunsaturated $n-3$ fatty acids $20: 5 n-3$ and $22: 6 n-3)$ per $\mathrm{kg}$ per day. The former can be used when studies using the same species are compared, while for interspecies comparison the latter is preferable. The differences in the bodyweights of rabbits and the type of oil (organic extracts or transethylesterified lipids) with different n-3 fatty acid content invalidate any comparison within this species. The degree of incorporation of $20: 5 n-3$ and $22: 6 n-3$ into plasma phospholipids might be an indication for an effective dose, but to date only one study [28] reports on the fatty acid distribution of plasma phospholipids after fish oil feeding. The most consistent element throughout the studies in rabbits, pigs and monkeys appears to be the way atherosclerosis is measured in their vessels. In rabbits most frequently a macroscopic lipid stain is used and atherosclerosis is assessed by planimetry of intimal sudanophilia. In other studies using rabbits the amount of aortic lipids or intimal thickness is assessed or the number of foam cells counted. In the larger mammals, the aortic lipid content and coronary luminal encroachment most often are the parameters for atherosclerosis.
When scrutinizing the outcome of the studies (Tables 2-4), one must conclude that the fish oil effects are not species-dependent (both positive and negative results are found in all three species), not dosedependent, nor is there a relationship with the duration of the study. In all studies the number of animals used is comparable (from five to twelve). After judging the results of the twelve rabbit studies and classifying them very globally one can conclude that an equal number of studies report a favorable $[60,64,66,67]$, unfavorable $[58,62,65,68]$ or no effect $[59,61,63,69)$. For the swine studies four $[23,71-73]$ are favorable and two $[28,70]$ show no effect, while in the non-human primates two $[74,75]$ are beneficial and one study [76] shows no effect at all. It is most likely that some studies yielding negative results have not appeared in the international literature. In this respect it is of interest to cite the recent paper by Ravnskov [77] in which he compared the frequency of citation with the outcome of all cholesterol lowering trials using coronary heart disease or death as endpoints and found that positive studies were cited almost six times more often than negative ones. That sample size can be of major importance in determining the out- 
Table 4. Studies on the effect of fish oil on atherogenesis in hypercholesterolemic non-human primates

\begin{tabular}{|c|c|c|c|c|c|c|}
\hline & $\begin{array}{l}\text { Time } \\
\text { (months) }\end{array}$ & $\begin{array}{l}\text { Dose of EPA } \\
\text { and/or DHA }\end{array}$ & $\mathrm{I} / \mathrm{S}$ & $\begin{array}{l}\text { Blood } \\
\text { vessel } \\
\text { studied }\end{array}$ & $\begin{array}{l}\text { Assessment of } \\
\text { atherosclerosis }\end{array}$ & Effect of fish oil \\
\hline \multirow[t]{5}{*}{ Davis et al. ${ }^{74}$} & \multirow[t]{5}{*}{12} & $\begin{array}{l}12.5 \% \text { menhaden oil/day: } \\
5.5(\mathrm{EPA})+3.75 \\
\text { (DHA) weight } \% \text { in diet }\end{array}$ & \multirow[t]{5}{*}{ I } & \multirow[t]{2}{*}{ Aorta } & intimal thickness & $\downarrow$ \\
\hline & & & & & \%lesions & $\downarrow$ \\
\hline & & $18.8 \%$ menhaden oil/day: & & \multirow{2}{*}{$\begin{array}{l}\text { Carotid ar- } \\
\text { tery }\end{array}$} & $\begin{array}{l}\text { aortic lipids } \\
\text { intimal thickness }\end{array}$ & \\
\hline & & $\begin{array}{l}8.25(\mathrm{EPA})+5.63 \\
\text { (DHA) weight \% diet }\end{array}$ & & & \%lesions & $\downarrow$ \\
\hline & & & & $\begin{array}{l}\text { Femoral ar- } \\
\text { tery }\end{array}$ & \%lesions & $\downarrow$ \\
\hline \multirow[t]{5}{*}{ Parks et al. ${ }^{75}$} & \multirow[t]{5}{*}{$30-36$} & \multirow[t]{5}{*}{700 total $\mathrm{n}-3(\mathrm{mg} / \mathrm{kg} /$ day $)$} & \multirow[t]{5}{*}{ I } & Aorta & \%lesions & $\downarrow$ \\
\hline & & & & & LE & $=$ \\
\hline & & & & & aortic lipids & $\mathrm{CE} \downarrow ; \mathrm{FC}=$ \\
\hline & & & & $\begin{array}{l}\text { Coronary ar- } \\
\text { tery }\end{array}$ & LE & $\downarrow$ \\
\hline & & & & $\begin{array}{l}\text { Carotid ar- } \\
\text { tery }\end{array}$ & \%lesions & $\downarrow$ \\
\hline \multirow[t]{3}{*}{ Fincham et al. ${ }^{76}$} & \multirow[t]{3}{*}{20} & \multirow[t]{3}{*}{$\begin{array}{l}30.1 \mathrm{EPA}+9.7 \mathrm{DHA} \\
(\mathrm{mg} / \mathrm{kg} / \text { day })\end{array}$} & \multirow[t]{3}{*}{$\mathrm{I}$} & \multirow{3}{*}{$\begin{array}{l}\text { Aorta } \\
\text { Peripheral } \\
\text { arteries } \\
\text { Coronary ar- } \\
\text { tery }\end{array}$} & $\begin{array}{l}\text { overall score of } 16 \text { vari- } \\
\text { ables }^{\mathrm{a}}\end{array}$ & $\begin{array}{l}\hat{\delta}=; q \uparrow \\
=\end{array}$ \\
\hline & & & & & idem & $\delta=; q \uparrow$ \\
\hline & & & & & idem & \\
\hline
\end{tabular}

EPA, eicosapentaenoic acid (20:5n-3); DHA, docosahexaenoic acid (20:6n-3); aamong which plaque area, lesion free area, maximum lesion depth fibrous plaque, cholesterol clefts, foam cells, endothelial loss, intimal thickening, smooth muscle cell hyperplasia, proteoglycan infiltration, inflammation, medial mineralization score; ${ }^{b}$ common iliac, subclavian, brachiocephalic, carotid, basilar, cerebral arteries. I/S, isocaloric or supplementary administration of fish oil; \%lesions stands for the percentage of the surface of the vessel that is covered with intimal lesions; LE, luminal encroachment; FC, free cholesterol; CE, esterified cholesterol; TC, total cholesterol; Effect of fish oil: $=$, unchanged; $\downarrow$, decrease, $\uparrow$, increase.

come of the study was shown by Rich and colleagues [69] who after having analyzed one third of the rabbits, found a statistically significant effect favouring the fish oil treated group. However, because of the variability of aortic atherosclerosis as found in Watanabe hyperlipidemic rabbits it was judged to expand the dietary groups to improve the validity of the results. Surprisingly after 28 animals statistical significance was not reached and therefore the preventive effect of $n-3$ fatty acids was lost. Another observation that deserves attention is the finding that fish oil consistently decreases plasma triglycerides, but that the effect on plasma cholesterol is ambiguous. Accordingly, the anti-atherogenic effect in models employing hypercholesterolemia may be modest.

In summary, the diversity in species, dose, duration of study, methods, type of vessel studied, type of fish oil preparation (content of $n-3$ fatty acids; unesterified n-3 fatty acids, ethylesters or triglycerides) could all contribute to the until now equivocal results in the animal studies. Furthermore, the definitions and criteria used in the literature to evaluate atherogenesis are diverse and from our study [28] and other reports $[60,75]$ it appears that while one parameter is affected, another is not necessarily modified in the same direction, stressing the importance of extending the analysis of the effects on atherogenesis to more than one parameter.

\section{Animal studies with accelerated graft-arteriosclerosis}

Grafting veins into the arterial system is another model in which accelerated atherogenesis occurs and is of clinical interest as it embodies the patient with venous coronary bypasses. The basis for intimal thickening in these grafted vessels is unknown. It must be noted that veins are supplied abundantly by vasa vasorum. Since veins contain poorly oxygenated blood, the cells of veins would probably need more oxygen through other pathways. Furthermore as opposed to arteries, veins are under low pressure and the vénous vasa vasorum are unlikely to collapse and they can approach the lumen of the vessel wall. After grafting, this route of nutrient flow to the vessel wall may be interrupted. If a graft is implanted in another animal an immunological component of atherogenesis is introduced, mimicking the conditions in hearttransplant patients.

The major rationale for using fish oil in these models derives from the anti-thrombotic and anti- 
Table 5. Animal studies on the effect of fish oil on vessel graft atherogenesis

\begin{tabular}{|c|c|c|c|c|c|c|c|c|c|}
\hline & Animal & Model & $\begin{array}{l}\text { Time } \\
\text { (months) }\end{array}$ & $\begin{array}{l}\text { Dose of EPA } \\
\text { and/or DHA }\end{array}$ & $\mathrm{I} / \mathrm{S}$ & Effect & $\begin{array}{l}\text { Blood } \\
\text { vessel }\end{array}$ & $\begin{array}{l}\text { Assessment of } \\
\text { atherosclerosis }\end{array}$ & $\begin{array}{l}\text { Effect of } \\
\text { fish oil }\end{array}$ \\
\hline $\begin{array}{l}\text { Sarris } \\
\quad \text { et al. }{ }^{78}\end{array}$ & $\operatorname{dog}$ & $\begin{array}{l}\text { veno-arterial auto- } \\
\text { graft }+ \text { hyper- } \\
\text { cholesterolemia }\end{array}$ & 3 & $\begin{array}{l}200 \mathrm{mg} / \mathrm{kg} / \mathrm{day} \\
\mathrm{EPA}\end{array}$ & $\mathrm{S}$ & $\mathrm{TC}=, \mathrm{Tg}=$ & $\begin{array}{r}\text { venous } \\
\text { graft }\end{array}$ & $\begin{array}{l}\text { intimal thick- } \\
\text { ness }\end{array}$ & $\downarrow$ \\
\hline $\begin{array}{l}\text { Landymore } \\
\text { et al. }{ }^{79}\end{array}$ & $\operatorname{dog}$ & $\begin{array}{l}\text { veno-arterial auto- } \\
\text { graft }+ \text { hyper- } \\
\text { cholesterolemia }\end{array}$ & 1.5 & $\begin{array}{l}240 \text { or } 480 \mathrm{mg} / \mathrm{kg} / \\
\text { day EPA }\end{array}$ & $\mathrm{S}$ & $\mathrm{TC}=$ & $\begin{array}{r}\text { venous } \\
\text { graft }\end{array}$ & $\begin{array}{l}\text { intimal thick- } \\
\text { ness }\end{array}$ & $\begin{array}{l}\downarrow \text { (not } \\
\text { dose- } \\
\text { depen- } \\
\text { dent) }\end{array}$ \\
\hline $\begin{array}{l}\text { Cahill } \\
\text { et al. }{ }^{80}\end{array}$ & $\operatorname{dog}$ & $\begin{array}{l}\text { veno-arterial auto- } \\
\text { graft + hyper- } \\
\text { cholesterolemia }\end{array}$ & 3 & $200 \mathrm{mg} /$ day EPA & $\mathrm{S}$ & $\mathrm{TC} \uparrow$ & $\begin{array}{r}\text { venous } \\
\text { graft }\end{array}$ & $\begin{array}{l}\text { intimal thick- } \\
\text { ness }\end{array}$ & $\downarrow$ \\
\hline $\begin{array}{l}\text { Casali } \\
\text { et al. }^{83}\end{array}$ & $\operatorname{dog}$ & $\begin{array}{l}\text { synthetic graft in } \\
\text { femoral artery }\end{array}$ & 6 & $? ?$ & $\mathrm{~S}$ & $\mathrm{TC}=$ & $\begin{array}{l}\text { synthetic } \\
\text { graft }\end{array}$ & $\begin{array}{l}\text { histologic grad- } \\
\text { ing }\end{array}$ & $i$ \\
\hline $\begin{array}{l}\text { DeCampli } \\
\text { et al. }{ }^{82}\end{array}$ & $\operatorname{dog}$ & $\begin{array}{l}\text { veno-arterial allo- } \\
\text { graft }+ \text { hyper- } \\
\text { cholesterolemia }\end{array}$ & 3 & $\begin{array}{l}100 \mathrm{mg} / \text { day EPA } \\
+1200 \mathrm{mg} / \text { day } \\
\text { DHA }\end{array}$ & $\mathrm{S}$ & $\mathrm{nm}$ & $\begin{array}{r}\text { venous } \\
\text { graft }\end{array}$ & $\begin{array}{l}\text { angiogram } \\
\text { intimal thick- } \\
\text { ness }\end{array}$ & $\begin{array}{l}= \\
=\end{array}$ \\
\hline $\begin{array}{l}\text { Sarris } \\
\text { et al. }{ }^{83}\end{array}$ & rat & $\begin{array}{l}\text { heterotopic heart } \\
\text { transplant }\end{array}$ & 3 & $\begin{array}{l}130 \mathrm{mg} / \mathrm{kg} / \mathrm{day} \\
\mathrm{EPA}+80 \mathrm{mg} / \\
\mathrm{kg} / \text { day DHA }\end{array}$ & I & $\mathrm{nm}$ & $\begin{array}{c}\text { coronary } \\
\text { artery }\end{array}$ & $\begin{array}{l}\text { histologie grad- } \\
\text { ing }\end{array}$ & $\downarrow$ \\
\hline Yun et al. ${ }^{84}$ & rat & $\begin{array}{l}\text { heterotopic heart } \\
\text { transplant }\end{array}$ & 3 & $\begin{array}{c}136.6 \mathrm{mg} / \mathrm{kg} / \mathrm{day} \\
\mathrm{EPA}+95 \mathrm{mg} / \\
\mathrm{kg} / \mathrm{day} \mathrm{DHA}\end{array}$ & I & $\mathrm{TC}=, \mathrm{Tg}=$ & $\begin{array}{l}\text { coronary } \\
\text { artery }\end{array}$ & $\begin{array}{l}\text { intimal thick- } \\
\text { ness }\end{array}$ & $=$ \\
\hline Yun et al. ${ }^{8 \pi}$ & rabbit & $\begin{array}{l}\text { heterotopic heart } \\
\text { transplant }\end{array}$ & $1 . \overline{0}$ & $\begin{array}{c}29,87 \text { or } 174 \mathrm{mg} / \\
\mathrm{kg} / \text { day } \mathrm{EPA}\end{array}$ & I & $\begin{array}{l}\mathrm{TC} \downarrow \text { (high } \\
\text { dose) }\end{array}$ & $\begin{array}{r}\text { coronary } \\
\text { artery }\end{array}$ & $\begin{array}{l}\text { intimal thick- } \\
\text { ness }\end{array}$ & $\begin{array}{l}\uparrow \text { (dose } \\
\text { depen- } \\
\text { dent) }\end{array}$ \\
\hline
\end{tabular}

EPA, eicosapentaenoic acid (20:5n-3); DHA, docosahexanoic acid (20:6n-3); I/S, isocaloric administration of fish oil or supplemented to the food; TC, total plasma cholesterol; Tg, plasma triglycerides; $\mathrm{nm}$, not measured; Effect of fish oil: =, unchanged; $\downarrow$, decrease; $\uparrow$ increase.

inflammatory potential of fish oil. Table 5 lists the studies exploring the effects of fish oil on allo- or autografted veins and arteries. The studies on arterialized venous [78-80] or synthetic [81] grafts are uniform in their outcome: fish oil reduces the extent of accelerated graft intimal proliferation, while not reducing the hypercholesteremia. All studies used dogs, added the fish oil as a supplement to the diet and measure intimal thickness of the graft or used a histologic grading system for intimal thickness, but only the dose of fish oil and the duration of the study varied. After 6 weeks graft intimal thickness of the non-treated hypercholesterolemic animals averages $39 \mu \mathrm{m}$ versus $24 \mu \mathrm{m}$ (240 mg 20:5n-3/kg/day) and $23 \mu \mathrm{m}(480 \mathrm{mg} \mathrm{20:5 \textrm {n } - 3 /}$ $\mathrm{kg} /$ day) in the fish oil treated groups [79], demonstrating the lack of dose-dependency. After 3 months graft intimal proliferation of the control group is markedly higher (125 $\mu \mathrm{m} \mathrm{[80]} \mathrm{and} 143 \mu \mathrm{m}$ [78]) and the effect of fish oil somewhat greater (54\% decrease [80] and $46 \%$ decrease [78]). In the study by Casali et al. [81] no data on intimal thickening are presented, but the authors state that there was a significant reduction ( $p$ $<0.04$ ) in the fish oil treated normocholesterolemic animals. In this study the dose of $n-3$ fatty acids can not be calculated as the dogs are fed mackerel fish supplemented with menhaden oil.

In the remaining studies [82-85], the immunologic factor in graft-atherogenesis likely predominates. The three heterologic heart-transplant studies are homogeneous in design, but contradictory in the outcome as in one study using the Lewis rat as the recipient and the Brown-Norway rat as the donor there is a decrease [83], while in another study from the same group [84], where the Lewis rat donates its heart to the Brown-Norway rat no beneficial effect on allograft coronary atherosclerosis was found. A third study in rabbits [85] even showed a dose-dependent increase in coronary atherosclerosis.

In summary, dietary fish oil has been consistently effective in preventing accelerated graft intima proliferation in veno-arterial autografting, while in the heterotopic heart-transplant model the results are inconclusive.

\section{Restenosis after percutaneous transluminal coronary angioplasty in patients}

The high incidence of restenosis is a drawback of percutaneous coronary angioplasty. Table 6 contains all restenosis studies [86-94] with fish oil published in the English literature. With the exception of the study by Bowles et al. [92] all studies include a control group. Comparison of the studies is complicated. Pretreatment with fish oil appears relevant as it takes weeks for the ingested $20: 5 n-3$ and $22: 6 n-3$ to be incorporated into the cell membranes and platelet deposition with subsequent local release of growth factors occurs very early after balloon injury of a vessel. Of the five studies without pretreatment two are negative $[88,92]$, two $[86,91]$ are positive and one [90] is positive based on clinical restenosis rate but negative when assessed by subsequent selective coronary angiography. On the other hand, two studies $[89,94]$ are 
Table 6. Studies on the effect of fish oil on the restenosis-rate after angioplasty

\begin{tabular}{|c|c|c|c|c|c|c|c|}
\hline & $\begin{array}{l}\text { Pre- } \\
\text { treatment } \\
\text { (days) }\end{array}$ & $\begin{array}{l}\text { EPA } \\
\text { (g/day) }\end{array}$ & $\begin{array}{l}\text { DHA } \\
\text { (g/day) }\end{array}$ & $\begin{array}{l}\text { Duration } \\
\text { Follow } \\
\text { up } \\
\text { (months) }\end{array}$ & Evaluation & $\begin{array}{l}\text { (\% patient/ } \\
\text { \%patient) }\end{array}$ & $\begin{array}{l}\text { FO/ } \\
\text { control } \\
\text { P-value }\end{array}$ \\
\hline Slack et al..$^{86}$ & - & $?$ & & 6 & exercise-test & $\begin{array}{l}16 / 33^{\mathrm{a}} \\
67 / 58^{\mathrm{b}}\end{array}$ & $\begin{array}{l}\mathrm{P}<0.05 \\
\mathrm{NS}\end{array}$ \\
\hline Dehmer et al. ${ }^{87}$ & 7 & 3.2 & 2.2 & $3-4$ & coronary angiography & $19 / 46$ & $P=0.007$ \\
\hline Grigg et al. ${ }^{88}$ & - & 1.8 & 1.2 & 3.5 & coronary angiography & $34 / 33$ & NS \\
\hline Reis et al. ${ }^{89}$ & 5.4 & $\begin{array}{c}6.0 \text { (total } \\
n-3)\end{array}$ & & 6 & $\begin{array}{l}\text { stepwise: } \\
\text { clinical restenosis } \\
\text { selective coronary angiography 937\%) }\end{array}$ & $\begin{array}{l}35 / 24^{\mathrm{c}} \\
34 / 23^{\mathrm{c}}\end{array}$ & $\begin{array}{l}\text { NS } \\
\text { NS }\end{array}$ \\
\hline Milner et al. ${ }^{90}$ & - & 3.2 & 1.4 & 6 & $\begin{array}{l}\text { stepwise: } \\
\text { clinical restenosis } \\
\text { selective coronary angiography }(23 \%)\end{array}$ & $\begin{array}{l}22 / 35^{\mathrm{c}} \\
18 / 27^{\mathrm{c}}\end{array}$ & $\begin{array}{l}\mathrm{P}<0.008 \\
\mathrm{NS}\end{array}$ \\
\hline Nye et al. ${ }^{91}$ & - & 2.2 & 1.4 & 6 & coronary angiography & $11 / 30^{\text {de }}$ & $P<0.05$ \\
\hline Bowles et al. ${ }^{92}$ & - & 2.8 & $?$ & 6 & $\begin{array}{l}\text { coronary angiography }(56 \%) \\
\text { OR exercise scintygraphy }(30 \%) \\
\text { OR exercise electrocardiography ( } 4 \%) \\
\text { OR clinical restenosis }(9 \%)\end{array}$ & $\begin{array}{l}50 /- \\
23 /- \\
0 /- \\
9 /-\end{array}$ & $\begin{array}{l}? \\
? \\
? \\
?\end{array}$ \\
\hline Bairati et al..$^{98}$ & 21 & 2.7 & 1.8 & & coronary angiography & $22 / 40$ & $P=0.03$ \\
\hline Kaul et al. ${ }^{94}$ & 4.3 & 1.8 & 1.2 & 6 & $\begin{array}{l}\text { stepwise: } \\
\text { clinical restenosis } \\
\text { coronary angiography }(36 \%)\end{array}$ & $\begin{array}{l}38 / 29 \\
33 / 27\end{array}$ & $\begin{array}{l}\text { NS } \\
\text { NS }\end{array}$ \\
\hline
\end{tabular}

EPA, eicosapentaenoic acid (20:5n-3); DHA, docosahexaenoic acid (20:6n-3); FO, fish oil-treated group of patients; control, control group; ${ }^{\text {a }}$ one vessel disease; bmultivessel disease; "based on "intention to treat" principle; d\%lesions/\%lesions; "17\% in aspirin/dipyridamole-treated patients.

negative despite pretreatment. These results suggest that pretreatment neither guarantees nor is a prerequisite to the lower incidence of restenosis by fish oil. The doses of fish oil used in the various studies range from $2.8 \mathrm{~g}$ to $6.0 \mathrm{~g}$ per day (total $\mathrm{n}-3$ fatty acids), but this also does not seem to influence the outcome. The most important variable in these studies is the method by which restenosis was assessed. Angiography seems to be the most appropriate approach as restenosis is observed angiographically in 11-33\% of patients without symptoms or with the negative exercise tests [95]. Coronary angiography was conducted in almost all patients in four studies $[87,88,91,93]$ and selectively in four $[89,90,92,94]$, while in the study by Slack et al. [86] only exercise tests were evaluated.

O'Connor and colleagues have recently performed a meta-analysis of seven [86-91,94] studies (see also Table 6) [96] and concluded that fish oil yields a small to moderate reduction in restenosis rate $(6-46 \%)$. The large range was due to the small sample size of the studies (82-194 patients) and therefore only a randomized clinical trial involving over 880 patients can reliably answer the question whether fish oil is effective as a non-pharmacological adjuvant in the prevention of restenosis. A lower dose should be used since this seems more effective and fewer side effects are encountered. The two studies [92,94] added in the present paper do not basically alter such a recommendation. Moreover, two large scale trials, EMPAR and FORT are currently recruiting patients [97] and we can hopefully draw final conclusions after the results of these studies have been published.

\section{Fish Oil and the Regression of Atherosclerosis}

Schwartz et al. [98] have reviewed the possible targets for stabilization and regression of atherosclerotic lesions and states that regression undoubtedly is a resultant of the dynamic equilibrium of components of mechanisms involved in initiation, progression, stabilization, and size reduction (removal of plaque components), the latter being true regression. Fish oil, through its anti-thrombotic and other actions may influence the first three processes, as described before (Table 1). However, the effect on genuine regression, involving mobilization of the extracellular lipid core, on the reverse cholesterol transport, removal of residual plaque fibrin and plaque collagen has not been extensively studied [98].

Pure regression of experimental atherosclerotic lesions has been shown in chick [99], dog [100], swine [101] and non-human primates [102], leaving no doubt that relatively advanced lesions can reduce in size over time. Although human lesions may be more mature when treatment gets started, rendering the lesions more fatty, cellular and fibrous, regression of lesions has been shown in several studies [103-105]. In addition to cholesterol lowering [105], intervening in the cellular and molecular mechanisms of true regression may even be more effective, and possibly dietary fish oil can be of assistance. For instance, fish oil might change the physical and chemical state of plaque lipids, as well as the fluidity of plaque cellular components. 
Table 7. Animal studies on the effect of fish oil on the regression of atherogenesis

\begin{tabular}{|c|c|c|c|c|c|c|c|c|c|}
\hline \multirow[b]{2}{*}{ Author } & \multirow[b]{2}{*}{ Animal model } & \multicolumn{2}{|c|}{ Time (months) } & \multirow{2}{*}{$\begin{array}{l}\text { Dose of EPA } \\
\text { and } / \text { or DHA } \\
\text { (mg/kg/day) }\end{array}$} & \multirow[b]{2}{*}{$\mathrm{I} / \mathrm{S}$} & \multirow{2}{*}{$\begin{array}{l}\text { Effect on } \\
\text { plasma lipids }\end{array}$} & \multirow{2}{*}{$\begin{array}{l}\text { Blood vessel } \\
\text { studied }\end{array}$} & \multirow{2}{*}{$\begin{array}{l}\text { Parameter of } \\
\text { atherosclerosis }\end{array}$} & \multirow[b]{2}{*}{ Effect of fish oil } \\
\hline & & Induction & Regression & & & & & & \\
\hline Sassen et al. ${ }^{106}$ & $\begin{array}{c}\text { hypercholester- } \\
\text { olemic swine } \\
+ \text { abrasion }\end{array}$ & 4 & 3 & $\begin{array}{l}188^{\mathrm{a}}-210^{\mathrm{b}} \text { EPA } \\
125^{\mathrm{a}}-140^{\mathrm{b}} \text { DHA } \\
380^{\mathrm{a}}-396^{\mathrm{b}} \text { EPA } \\
209^{\mathrm{a}}-220^{\mathrm{b}} \text { DHA }\end{array}$ & I & $\mathrm{TC} \downarrow, \mathrm{Tg} \downarrow$ & $\begin{array}{l}\text { Aorta } \\
\text { Coronary artery }\end{array}$ & $\begin{array}{l}\text { Lipids } \\
\text { LE }\end{array}$ & $\begin{array}{l}\mathrm{PL}=; \mathrm{TC}=; \\
\mathrm{TG}= \\
\downarrow \text { (dose depen- } \\
\text { dent) }\end{array}$ \\
\hline Zhu et al. ${ }^{107}$ & $\begin{array}{l}\text { hypercholester- } \\
\text { olemic rabbit }\end{array}$ & 2.5 & 10 & $\begin{array}{l}82^{\mathrm{a}-}-73^{\mathrm{b}} \text { EPA } \\
55^{\mathrm{a}}-49^{\mathrm{b}} \text { DHA }\end{array}$ & S & $\mathrm{TC}=, \mathrm{Tg}=$ & $\begin{array}{l}\text { Aorta } \\
\text { Pulmonary ar- } \\
\text { tery }\end{array}$ & $\begin{array}{l}\text { LS } \\
\text { LS }\end{array}$ & $\downarrow$ \\
\hline \multirow[t]{2}{*}{ Fincham et al. ${ }^{76}$} & $\begin{array}{l}\text { hypercholester- } \\
\text { olemic non- } \\
\text { human pri- } \\
\text { mate }\end{array}$ & 24.5 & 20 & $\begin{array}{l}30.1 \mathrm{EPA} \\
9.7 \mathrm{DHA}\end{array}$ & I & $\mathrm{TC}=, \mathrm{Tg}=$ & Aorta & $\begin{array}{l}\text { LE } \\
\text { \%lesions }\end{array}$ & $\begin{array}{l}= \\
=\end{array}$ \\
\hline & & & & & & & $\begin{array}{l}\text { Cerebral artery } \\
\text { Coronary artery }\end{array}$ & $\begin{array}{l}\mathrm{LE} \\
\mathrm{LE}\end{array}$ & $\begin{array}{l}= \\
=\end{array}$ \\
\hline Sassen et al. ${ }^{28}$ & $\begin{array}{l}\text { swine } \\
+ \text { abrasion } \\
\text { + bile acids }\end{array}$ & 8 & 4 & $\begin{array}{l}309^{a}-193^{b} \text { EPA } \\
220^{a}-137^{b} \text { DHA }\end{array}$ & I & & $\begin{array}{l}\text { Aorta } \\
\text { - ascending } \\
\text { (non-abraded) } \\
\text { - abdominal } \\
\text { (abraded) } \\
\text { Coronary artery }\end{array}$ & $\begin{array}{l}\text { \%lesion } \\
\text { Lipids } \\
\text { Lipids } \\
\text { LE }\end{array}$ & $\begin{array}{l}= \\
\mathrm{Pl}=; \mathrm{CE} \downarrow ; \mathrm{FC} \\
\quad=; \mathrm{TG}= \\
\mathrm{PL}=; \mathrm{CE}=; \\
\quad \mathrm{PC}=; \mathrm{TG}= \\
=\end{array}$ \\
\hline
\end{tabular}

EPA, eicosapentaenoic acid (20:5n-3); DHA, docosahexaenoic acid $(20: 6 n-3)$; adose at the beginning of the dietary period; bose at the end of the dietary period; I/S, isocaloric or supplementary administration of fish oil; \%lesions stands for the percentage of the surface of the vessel that is covered with intimal lesions; LE, luminal encroachment; PL, phospholipids; FC, free cholesterol; CE, esterified cholesterol; $\mathrm{TC}$, total cholesterol; $\mathrm{Tg}$, triglycerides.

So far, only four studies $[28,76,106,107]$ reported on the additive effects of fish oil on the regression of atherosclerosis (Table 7). In swine, atherosclerosis was induced by endothelial denudation and high cholesterol feeding for 4 months, after which the animals were put on a low-cholesterol, fish oil (two doses) containing diet for 3 months [106]. Fish oil retarded the progression and caused regression of coronary atherosclerosis. In a second study [28] addition of $0.5 \%$ of bile acids to the diet and an induction period of 8 months did not lead to a higher degree of atherosclerosis in the control group (intimal proliferation of $13.4 \%$ versus $11 \%$ in [28]) despite higher levels of plasma cholesterol. However, in that study [28] the subsequent post-induction period did not lead to regression of the severity of coronary atherosclerosis. The fact that the induction period was twice as long may have contributed to the development of lesions, which may have become more resistant to fish oil treatment. In accordance with the previous study, fish oil prevented progression of established lesions. Fincham et al. [76] (24.5 months of induction and 20 months of postinduction) found that in the African green monkey fish oil (as compared to safflower oil) did not cause regression of coronary atherosclerosis and, if anything, worsened aortic atherosclerosis as measured by an overall score of 16 variables such as presence of foam cells, endothelial loss and cholesterol clefts (see also Table 7). On the other hand Zhu et al. [107], demonstrated that fish oil significantly reduced the amount of sudanophilic lesions in rabbit aorta and pulmonary artery. We also found a decrease in sudanophilic coverage in the two post-induction groups, but there was no difference between the groups [28]. However, aortic atherosclerosis assessed by lipid content (free and esterified cholesterol and phospholipids) of the lesions, was significantly lowered by fish oil, emphasizing the importance of the definition of/and the criteria used for atherosclerosis to draw conclusions.

\section{Conclusions}

Most studies investigating the effects of dietary fish oil on the progression of atherosclerosis in hypercholesterolemic animal models are difficult to compare because of the diversity in species, dose of fish oil used, duration of study, type of vessel studied, variable used for the assessment of severity of atherosclerosis, etc. However, generally, aside from these problems of dissimilarity of the hypercholesterolemic animal studies one can state that the number of positive studies are matched by the number of negative studies showing no effect or an adverse effect. Since atherosclerosis is a multifactorial disease and high levels of plasma cholesterol are surely not the only causative factor in atherosclerosis, the effects of fish oil must be evaluated in the light of the reported other beneficial effects of fish oil (i.e., effects on platelet function, arterial blood pressure and inflammatory processes). It seems that in models where platelet aggregation is the most prominent factor in generating accelerated atherogenesis (the veno/synthetic graft)-arterial autografting model) fish oil is effective while in models where an immunological component of atherogenesis dominates other causes fish oil is ineffective. Therefore it could be of interest to evaluate the effects of fish oil on restenosis in patients after coronary bypass grafting after a period of years. In the studies on restenosis after angioplasty, undoubtedly consisting of 
patient populations with a mixed type of atherogenesis-promoting factors, firm conclusion as to the effectiveness of fish oil can not be drawn because there is not (yet) a unidirectional trend. We agree with others [96] that a large trial evaluating the effect of fish oil on restenosis in angioplasty patients by coronary angiography may provide an answer. We also believe that it is time to reach a consensus as to which animal models mimic most closely a particular human situation. Only in appropriate models, investigating more than one atherosclerosis variable, the effects of a putative anti-atherogenic drug/diet can be verified.

Maybe it is also time to temper the overrated expectations of the therapeutic effect of $n-3$ fatty acids. In this respect, it is of interest to note that also the capability of $n-3$ fatty acid-rich diets to reduce the incidence of ischemic heart disease has been questioned. In the seventies Dyerberg and coworkers explained the differences in lipoprotein levels between the Eskimos living in the Uumannaq district on the Westcoast of Greenland and Danish controls by the high level of $n-3$ fatty acids in the natural diet of the Greenland Inuit population, rather than by genetic differences. However, distinct indications for genetic heterogeneity between Danes and Westcoast Greenland Eskimos have emerged [108]. Recently, a group of Eskimos living in the Nortalik district on the Southcoast of Greenland, primarily of Inuit origin and genetically different from the Westcoast Eskimos, were not only shown strongly to resemble Caucasians regarding their lipoprotein levels and plasma cholesterol ester fatty acid composition but also regarding their lifestyle (smoking, alcohol consumption and diet) [109]. Even those Inuit (13\%) whose diet is still restricted to meat of fish and marine mammals exhibit a 'Western' fatty acid profile of plasma cholesterolester, demonstrating the influence of genetic factors. Although the incidence of ischemic heart disease among the Eskimos is still low, the degree of atherosclerosis as measured by ultrasound [110] or by X-ray of the abdominal aorta [111] is similar as in Danes. It is thus quite feasible that genetic factors may prove to be more vital than dietary regimen to explain the lower incidence of ischemic heart disease in Greenland Eskimos. It has also been questioned if the abstinence from meat from mammals living on land rather than the consumption of fish and fish products can cause differences in the incidence in ischemic heart disease. In this respect, it is noteworthy that a vegetarian diet also contributes to the slowing down of lesion development [112].

The number of animal studies investigating the effects of fish oil on the regression of atherosclerosis, is too small to draw any conclusion, and, therefore further experimental work is required. Regression of human atherosclerosis is not an utopia [105], however, as yet, no attempts have been made to study the influence of $n-3$ fatty acids in the regression of human atherosclerosis.

\section{Acknowledgments}

This study was supported by grants from the Netherlands Heart Foundation (NHS, grant number 86.086) and the Netherlands Organization for Scientific Research (NWO, grant number 900562-111).

\section{References}

1. Dyerberg J, Bang HO, and Hjørne N. Fatty acid composition of the plasma lipids in Greenland Eskimos. Am J Clin Nutr 1975;28:958-966.

2. Bjerregaard P and Dyerberg J. Mortality from ischaemic heart disease and cerebrovascular disease in Greenland. Int J Epidemiol 1988;17:514-519.

3. Medini L, Colli S, Mosconi C, Tremoli E, Galli C. Diets rich in $n-9, n-6$ and $n-3$ fatty acids differentially affect the generation of inositolphosphates and thromboxans by stimulated platelets, in the rabbit. Biochem Pharmacol 1990;39:129-133.

4. Lamers JMJ, Dekkers DHW, De Jong N, Meij JTA. Modification of fatty acid composition of the phospholipids of cultured rat ventricular myocytes and the rate of phosphatidyl-4,5-bisphosphate hydrolysis. J Mol Cell Cardiol 1992; 24:605-618.

5. Lamers JMJ, Dekkers DHW, Bezstarosti K, Meij JTA, Van Heugten HAA. Occurrence and function of the phosphatidylinositolcycle in the myocardium. Mol Cell Biochem 1992;116:59-67.

6. Maldolesi J, Magni M. Lipid metabolites and growth factor action. TIPS 1991;12:363-364.

7. Davies PF, Tripathi SC. Minireview. Mechanical stress mechanisms and the cell. An endothelial paradigm. Circ Res 1993;72:239-245.

8. Sluiter W, Pietersma A, Lamers JMJ, Koster JF. Leukocyte adhesion molecules on the vascular endothelium. Their role in the pathogenesis of cardiovascular disease and the mechanisms underlying their expression. $J$ Cardiovasc Pharmacol 1993, 22(Suppl 4):S37-S44.

9. Rubyani GM. The role of endothelium in cardiovascular homeostasis and diseases. $J$ Cardiovasc Pharmacol 1993, 12(Suppl 4):S1-S14.

10. Hay CRM, Burber AP, Saynor R. Effect of fish oil on platelet kinetics in patients with ischemic heart disease. Lancet 1982;1:1269-1272.

11. Knapp HR, Reilly IAG, Aiessandrini P, Fitzgerald GA. In-vivo indeces on platelet and vascular function during fish oil administration in patients with atherosclerosis. $N$ Engl J Med 1986;314:937-942.

12. Sperling RI, Robin J-L, Kylander KA, et al. The effects of N2 polyunsaturated fatty acids on the generation of platelet activating factor by human monocytes. $J$ Immunol 1987;139:4186-4191.

13. Fisher S, Weber PC. Thromboxane A3 (TXA3) is formed in human platelets after dietary eicosapentaenoic acid (C20:5 omega-3). Biochem Biophys Res Commun 1983; 116:1091-1099.

14. Lamers JMJ, Hartog JM, Verdouw PD and Hülsmann WC. Dietary fatty acids and myocardial function. Basic Res Cardiol 1987;82:209-221.

15. Houwelingen van $R$, Nordov A, Beek van der E, et al. Effect of a moderate fish intake on blood pressure, bleeding 
time, hematology, and clinical chemistry in healthy males. Am J Clin Nutr 1987;46:424-436.

16. Harris WS, Connor WE, Goodnight SH Jr. Dietary fish oils, plasma lipids and platelets in man. Prog Lipid Res 1981;20:75-79.

17. Fox PL, DiCorieto PE. Fish oil inhibits endothelial cell production of platelet-derived growth factor-like protein. Science 1988;241:453-456.

18. Shimokawa H, Vanhoutte PM. Dietary cod-liver oil improves endothelium dependent responses in hypercholesterolemic and atherosclerotic porcine coronary arteries. Circulation 1989;78:1421-1430.

19. Vekshtein VI, Yeung AC, Vita JA, et al. Fish oil improves endothelium-dependent relaxation in patients with coronary artery disease. Circulation 1989;80(suppl II):II-434.

20. Herold PM, Kinsella JE. Fish oil consumption and decreased risk of cardiovascular disease: a comparison of findings from animal and human feeding trials. Am J Clin Nutr 1986;43:566-598.

21. Harris WS. Fish oil and plasma lipid and lipoprotein metabolism in humans: a critical review. $J$ Lipid Res 1989;30: 785-807.

22. Davidson MH. A symposium: Antioxidants and lipid metabolism. Implications for the present and directions for the future. Am J Cardiol 1993;71:32B-36B.

23. Kim DN, Ho HT, Lawrence DA, et al. Modification of lipoprotein patters and retardation of atherogenesis by a fish oil supplement to a hyperlipidemic diet for swine. Atherosclerosis $1989 ; 76: 35-54$.

24. Groot PHE, Scheek LM, Dubclaar ML, et al. Effects of diets supplemented with lard fat or mackerel oil on plasma lipoprotein lipid concentrations and lipoprotein lipase activities in domestic swine. Atherosclerosis 1989;77:1-6.

25. Edwards JJ, Gebre AK, Wagner WD, et al. Reduced proteoglycan binding of low density lipoproteins from monkeys (Macaca fascicularis) fed a fish oil versus lard diet. Arterioscler Thromb 1991;11:1778-1785.

26. Endres S, Ghorbani R, Kelly VE, et al. The effect of dietary supplementation with $n-3$ polyunsaturated fatty acids on the synthesis of interleukin-1 and tumor necrosis factor by mononuclear cells. $N$ Engl $J$ Med 1989;320: $265-271$.

27. Lee TH, Hoover RL, Williams JD, et al. Effects of dietary enrichment with eicosapentaenoic and docosahexaenoic acids on in vitro neutrophil and monocyte leukotriene generation and neutrophil function. $N E$ Egl $J \mathrm{Med}$ 1985;312: $1117-1224$

28. Sassen LMA, Lamers JMJ, Sluiter W, et al. Development and regression of atherosclerosis in swine: Effects of $n-3$ fatty acids, their incorporation into plasma and aortic plaque lipids and granulocyte function. Arterioscler Thromb 1993;13:651-660.

29. Schmidt EB, Pederson JO, Jersild C, Ditzel J, Grunnet N, Dyerberg $J$, The effect of $n-3$ polyunsaturated fatty acids on lipids, haemostasis, neutrophil and monocyte chemotaxis in insulin dependent diabetes mellitis. $J$ Intern Med 1989;225:201-206.

30. Morris MC, Snacks F, Romer B. Does fish oil lower blood pressure? A meta-analysis of controlled trials. Circulation $1993 ; 2: 523-534$.

31. Lorenz R, Spengler U, Fischer S, Duhm J, Weber PC. Platelet function, thromboxane formation and blood pressure control during supplementation of Western diet with cod liver oil. Circulation 1983;67:504-511.

32. Muller AD, Van Houwelingen AC, Van Dam-Mieras MC,
Bas BM, Hornstra G. Effect of a moderate fish intake on haemostatic parameters in healthy males. Thromb Haemost 1989;61:468-473.

33. Nilsen DW, Dalaker K, Nordoy A, et al. Influence of a concentrated ethylester compound of $n-3$ fatty acids on lipids, platelets and coagulation in patients undergoing coronary bypass surgery. Thromb Haemost 1991;66(2): 195-201.

34. Haines AP, Saunders TAB, Imeson JD, et al. Effects of fish oil supplement on platelet function, hemostatic variables and albuminuria in insulin-dependent diabetics. Thromb Res 1986;43:643-655.

35. Saldeen T, Mehta J, Lawson D. Reduction in plasminogen activator inhibitor-1 (PAI-1) with omega-3 PUFA intake. Fibrinolysis 1988;2:132.

36. Emeis JJ, Van Houwelingen AC, Van den Hoogen CM, Hornstra G. A moderate fish intake increases plasminogen activator inhibitor type-1 in human volunteers blood. Blood 1989;74(1):233-237.

37. Sanders TAB, Vickers M, Haines AP. Effect on blood lipids and haemostasis of a supplement of cod-liver oil, rich in eicosapentaenoic and docosahexaenoic acids, in healthy young men. Clin Sci 1981;61:317-324.

38. Hornstra G. Effect of fish oil feeding on arterial thrombosis, platelet function and blood coagulation. In: Dietary lip$i d s$, prostanoids and arterial thrombosis. Martinus Nijhoff Publishers, The Hague, pp 106-137.

39. Atkinson PM, Wheller MC, Mendelsohn D, Pienaar N, Chetty N. Effect of a 4-week freshwater fish (trout) diet on platelet aggregation, platelet fatty acids, serum lipids, and coagulation factors. Am J Hematol 1987;24:143-149.

40. Leaf A, Weber PC. Cardiovascular effects of $n-3$ fatty acids. $N$ Engl $J$ Med 1988;313:549-557.

41. Gibson RA. The effect of diets containing fish and fish oils on disease risk factors in humans. Aust NZ J Med 1988;18: $713-722$.

42. Willis AL, Smith DI. Therapeutic impact of eicosanoids in atherosclerotic disease. Eicosanoids 1989;2:69-99.

43. Leaf A. Cardiovascular effects of fish oil: Beyond the platelet. Circulation 1990;82(2):624-628.

44. Lamers JMJ, Sassen LMA. Hartog JM, Guarnieri C, Verdouw PD. Dietary N-3 polyunsaturated fatty acids and ischemic heart disease. In: Korecky B, Dhalla NS (Eds). Subcellular basis of cardiac contractile failure. Kluwer Academic Publishers, Norwell Mass, 1990; pp 237-256.

45. Israel DH, Gorlin R. Fish oil in the prevention of artherosclerosis. J Am Coll Cardiol 1992;19(1):174-185.

46. Lands WEM. Biochemistry and physiology of n-3 fatty acids. FASE $B J$ 1992;6:2530-2536.

47. Hornstra G. The significance of fish and fish-oil enriched food for prevention and therapy of ischaemic cardiovascular disease. In: Vergroessen AJ and Crawford M (Eds). The role of fats in human nutrition. Academic Press Limited, London, UK, 1989; pp 151-235.

48. St. Clair RW. Atherosclerosis regression in animal models: Current concepts of cellular and biochemical mechanisms. Prog Cardiovasc Dis 1983;26:109-132.

49. Clarkson TB, Lehner NDM, Bullock BC. Specialized research applications. Atherosclerosis research. In: Weisbroth SH, Flatt RE, Kraus AL (Eds). The biology of the laboratory rabbit. Academic Press, New York, 1974; pp 155-165.

50. Carroll KK. Hypercholesterolemia and atherosclerosis: effects of dietary proteins. Fed Proc 1982;41(11):2792-2796.

51. Luginbühl H, Jones JET, Getty R, et al. Part I. Athero- 
sclerosis in swine. In: Roberts Jr JC, Strauss R (eds). Comparative atherosclerosis. Harper and Row, New York, 1965; pp 3-42.

52. Rowsell HC, Mustard JF, Downie HG. Experimental atherosclerosis in swine. Ann NY Acad Sci 1965;127:743-762.

53. Lee WM, Lee KT. Advanced coronary atherosclerosis in swine produced by combination of balloon-catheter injury and cholesterol feeding. Exp Mol Pathol 1975;23:491-499.

54. Nam SC, Lee WM, Jarmolych J, et al. Rapid production of advanced atherosclerosis in swine by a combination of endothelial injury and cholesterol feeding. Exp Mol Pathol 1973;18:369-379.

55. Bevans M, Davidson JD, Abell LL, The early lesions of canine arteriosclerosis. AMA Arch Pathol 1951;51:278287.

56. Armstrong ML. Atherosclerosis in rhesus and cyanomolgus monkeys. Prim Med 1976;9:16-40.

57. Malinow MR, McLaughin P, Papworth L, et al. A model for therapeutic interventions on established coronary atherosclerosis in a nonhuman primate. Adv Exp Med Biol $1976 ; 67: 3+31$.

58. Thiery J, Seidel D. Fish oil feeding results in an enhancement of cholesterol-induced atherosclerosis in rabbits. Atherosclerosis $1987 ; 63: 53-56$.

59. Kristensen SD, Roberts KM, Lawry J, et al. The effect of fish oil on atherogenesis and thrombosis in rabbits on high cholesterol diet. Artery 1988;15(5):250-258.

60. Zhu BQ, Smith D, Sievers R, et al. Inhibition of atherosclerosis by fish oil in cholesterol-fed rabbits. $J$ Am Coll Cardiol 1988;12:1073-1078.

61. Campos CT, Michalek VN, Matts MP, et al. Dietary marine oil supplements fail to affect cholesterol metabolism or inhibit atherosclerosis with diet-induced hypercholesterolemia. Surgery 1989;106:177-184.

62. Rogers KA, Adelstein R. MaxEPA fish oil enhances cholesterol-induced intimal foam cell formation in rabbits. $A m J$ Pathol 1990;137(4):945-951.

63. Yamaguchi K, Mizota M, Hashizume H, et al. Antiatherogenic action of eicosapentaenoic acid (EPA) in multiple oral doses. Prostaglandins Leukotrienes and Medicine 1987;28: $35-43$.

64. Chen MF, Lee YT, Hsu HC, et al. Effects of dietary supplementation with fish oil on atherosclerosis and myocardial injury during acute sensory occlusion-reperfusion in diet-induced hypercholesterolemic rabbits. Int $J$ Cardiol 1992;35:323-331.

65. Hearn JA, Sgoutas DS, Robinson KA, et al. Marine lipid concentrate and atherosclerosis in the rabbit model. Atherosclerosis $1989 ; 75: 39-47$.

66. Bolton-Smith A, Gibney MJ, Gallagher PJ, et al. Effect of polyunsaturated fatty acids of the n-3 and n-6 series on lipid composition and cicosanoid synthesis of platelets and aorta and on immunological induction of atherosclerosis in rabbits. Atherosclerosis 1988;72:29-35.

67. Lichtenstein AH, Chobanian AV. Effect of fish oil on atherogenesis in watanabe heritable hyperlipidemic rabbit. Arteriosclerosis 1990;10:597-606.

68. Clubb FJ, Schmitz JM, Eutler M, et al. Effect of dietary omega-3 fatty acid on serum lipids, platelet function, and atherosclerosis in Watanabe heritable hyperlipidemic rabbits. Arteriosclerosis 1989;9:529-537.

69. Rich S, Miller JF, Charous S, et al. Development of atherosclerosis in genetically hyperlipidemic rabbits during chronic fish-oil ingestion. Arteriosclerosis 1989;9:189-194.
70. Hill EG, Lundberg WG, Titus JL. Experimental atherosclerosis in swine I. A comparison of menhaden-oil supplements in tallow and coconut-oil diets. Mayo Clin Proc 1971; 46:613-620.

71. Hill EG, Lundberg WQ. Titus JL. Experimental atherosclerosis in swine II. Effects of methionine and menhaden oil on an antherogenic diet containing tallow and cholesterol. Mayo Clin Proc 1971;46:621-625.

72. Weiner $\mathrm{BH}$, Oekene IS, Levine $\mathrm{PH}$ et al. Inhibition of atherosclerosis by cod-liver oil in a hyperlipidemic swine model. $N$ Engl J Med 1986;315:841-846.

73. Hartog JM, Lamers JMJ, Essed CE, et al. Does platelet aggregation play a role in the reduction in localized intimal proliferation in normolipidemic pigs with fixed coronary artery stenosis fed dietary fish oil? Atherosclerosis 1989;76: 79-88.

74. Davis HR, Bridenstein RT, Vesselinovitch D, et al. Fish oil inhibits development of atherosclerosis in rhesus monkeys. Arteriosclerosis 1987;7:441-449.

75. Parks JS, Kaduch-Sayer J, Bulldock BC, et al. Effect of dietary fish oil on coronary artery and aortic atherosclerosis in African green monkeys. Arteriosclerosis 1990;10: 1102-1112.

76. Fincham JE, Gouws E, Woodroof CW, et al. Atherosclerosis. Chronic effects of fish oil and a therapeutic diet in nonhuman primates. Arterioscler Thromb 1991;11:719-732.

77. Ravnskov U. Cholesterol lowering trials in coronary heart disease: frequency of citation and outcome. $\mathrm{Br} M e d J 1992$; 305:15-19.

78. Sarris GE, Fann JI, Sokoloff MH, et al. Mechanisms responsible for inhibition of vein-graft arteriosclerosis by fish oil. Circulation 1989;890(suppl I):I-109-I-123.

79. Landymore RW, Manku MS, Tan M, et al. Effects of lowdose marine oils on intimal hyperplasia in autologous vein grafts. J Thorac Cardiovasc Surg 1989;98:788-791.

80. Cahill PD, Sarris GE, Cooper AD, et al. Inhibition of vein graft intimal thickening by eicosapentanoic acid: reduced thromboxane production without change in lipoprotein levels or low-density lipoprotein receptor density. $J$ Vasc Surg 1988;7(1):108-118.

81. Casali RE, Hale JA, LeNarz LR, et al. Improved graft patency associated with altered platelet function induced by marine fatty acids in dogs. $J$ Surg Res 1986;40:6-12.

82. DeCampli WM, Kosek JC, Mitchell RS, et al. Effects of aspirin, dipyridamole, and cod liver oil on accelerated myointimal proliferation in canine veno-arterial allografts, Ann Surg 1988;208(6):746-754.

83. Sarris GE, Mitchell RS, Billingham ME, et al. Inhibition of accelerated cardiac allograft arteriosclerosis by fish oil. $J$ Thorac Cardiovasc Surg 1989;97:841-855.

84. Yun KI, Michie SA, Fann JI, et al. Effects of fish oil on graft arteriosclerosis and MHC Class II antigen expression in rate heterotopic cardiac allografts. J Heart Lung Transplant 1991;10:1004-1011.

85. Yun KL, Fann JI, Sokoloff $\mathbf{M H}$, et al. Dose response of fish oil versus safflower oil on graft arteriosclerosis in rabbit heterotopic cardiac allografts. Ann Surg 1991;214(2): 155-167.

86. Slack JD, Pinkerton CA, VanTassel J, et al. Can oral fish oil supplement minimize restenosis after percutaneous transluminal coronary angioplasty? J Am Coll Cardiol $1987 ; 9: 64 \mathrm{~A}$

87. Dehmer GJ, Popma JJ, Van den Berg EK, et al. Reduction in the rate of early restenosis after coronary angioplasty 
by a diet supplemented with n-3 fatty acids. $N E n g l J$ Med 1988;319:733-740.

88. Grigg LF, Kay TWH, Valentine PA, et al. Determinants of restenosis and lack of effect of dietary supplementation with eicosapentaenoic acid on the incidence of coronary artery restenosis after angioplasty. I Am Coll Cardiol 1989; 13:665-672.

89. Reis GJ, Boucher TM, Sipperly ME, Randomised trial of fish oil for prevention of restenosis after coronary angioplasty. Lancet $1989 ; 2(8656): 177-181$.

90. Milner MR, Gallino RA, Leffingwell A, et al, Usefulness of fish oil supplements in preventing clinical evidence of restenosis after percutaneous transluminal coronary angioplasty. Am J Cardiol 1989;64:294-299.

91. Nye ER, Ablett MB, Robertson MC, et al. Effect of eicosapentaenoic acid on restenosis rate, clinical course and blood lipids in patients after percutaneous transluminal coronary angioplasty. Aust NZ J Med 1990;20:549-552.

92. Bowles MH, Klonis D, Plavac TG, et al. EPA in the prevention of restenosis post PTCA. Angiology 1991;42(3): 187-194.

93. Bairati I, Roy L, Meyer F. Double-blind, randomized, controlled trial of fish oil supplements in prevention of recurrence of stenosis after coronary angioplasty. Circulation 1992;85:950-956.

94. Kaul U, Sanghvi S, Bahl VK, et al. Fish oil supplements for prevention of restenosis after coronary angioplasty. Int $J$ Cardiol 1992;35:87-93.

95. Zaidi AR, Hollman J, Galan K, et al. Predictive value of chest discomfort for restenosis following successful coronary angioplasty. Circulation 1985;72(Suppl III):-456.

96. O'Connor GT, Malenka DJ, Marsch Olmstead E, et al. A meta-analysis of randomized trials of fish oil in prevention of restenosis following coronary angiolasty. Am J Prev Med 1992;8(3):186-192.

97. Popma JJ, Califf RM, Topol FJ. Clinical trials of restenosis after coronary angioplasty. Circulation 1991;84:1426-1436.

98. Schwartz CJ, Valente AJ, Sprague EA, et al. Atherosclerosis: Potential targets for stabilization and regression. Circulation 1992;86(suppl III):III-117-III-123.

99. Horlick L, Katz LN. Retrogression of atherosclerotic le- sions on cessation of cholesterol feeding in the chick. J Lab Clin Med 1949;34:1427-1442.

100. Bevans M, Davidson JD, Kendall FE. Regression of lesions in canine arteriosclerosis. Arch Pathol 1951;51:288-292.

101. Daoud AS, Jarmolych J, Augustyn JM, et al. Regression of advanced swine atherosclerosis. Arch Pathol Lab Med 1976;100:372-379.

102. Armstrong ML, Warner ED, Connor WE. Regression of coronary atheromatosis in rhesus monkeys. Circ Res 1970; 27:59-67.

103. Ost RC, Stenson S. Regression of peripheral atherosclerosis during therapy with high doses of nicotinic acid. Scand $J$ Clin Lab Invest 1967;99:242-245.

104. Buchwald H, Moore RB, Rucker RD, et al. Clinical angiographic regression of atherosclerosis after partial ileal bypass. Atherosclerosis 1983;46:116-128.

105. Blankenhorn DH, Nessim SA, Johnson RL, et al. Beneficial effects of conformed Colestipol-niacin therapy on coronary atherosclerosis and coronary venous bypass grafts. JAMA 1987;257:3233-3240.

106. Sassen LMA, Hartog JM, Lamers JMJ, et al. Mackerel oil and atherosclerosis in pigs. Eur Heart $J$ 1989;10:838-846.

107. $\mathrm{Zhu} B Q$, Sievers $\mathrm{RE}$, Isenberg WM, et al. Regression of atherosclerosis in cholesterol-fed rabbits: Effects of fish oil and verapamil. JACC 1990;15(1):231-237.

108. Eriksson AW, Lehmann W, Simpson NE. Genetic studies on circumpolar populations. In Milan FA (ed): The Human biology of circumpolar populations . Cambridge, England, Cambridge University Press, 1979, pp 81-168.

109. De Knijff P, Johansen LG, Rosseneu M, et al. Lipoprotein profile of a Greenland Inuit population. Influence of anthropometric variables, ApoE and A4 polymorphism, and lifestyle. Arterioscler Thromb 1992;12:1371-1379.

110. Hart Hansen JP, Hancke S, Moller Peterson J. Atherosclerosis in native Greenlanders: An ultrasonic investigation. Arch Med Res 1990;49:151-156.

111. Ingeman-Nielsen M. Arteriosclerosis in Greenlanders. Eur $J$ Clin Invest 1991;21:72.

112. Ornish D, Brown SE, Scherwitz LW, et al. Can lifestyle changes reverse coronary heart disease? The Lifestyle Heart Trial. Lancet 1990;336(8707):P129-P133. 